\title{
The Story of Tethys:
}

\section{How many Wives Did Okeanos Have?}

\author{
by A.M. Celâl Şengör
}

For a century now the Tethys has been regarded as the ancestral sea out of which the Alpine-Himalayan mountain ranges grew. Plate tectonic theory initially identified it with an eastwards-opening triangular embayment within the Permo-Triassic Pangaea, but this led to a dilemma because the "classical" Tethys had not been born until the Triassic. In this review, the dilemma is resolved by recognising the former existence of another, older Tethys (PaleoTethys), a contemporary of Pangaea. Its closure formed the cimmeride orogenic system, which is distinct from, but largely ovexprinted by the Alpide orogenic system, a product of the demise of the "classical" Tethys (Neo-Tethys).

\section{Introduction}

Most Asiatic mythologies agree in placing into south-central Asia a former inland sea known as Ardvisura in Iran, as Süt-Ak-Köl in Turkestan, as Marvo in India, and as Han Hai in China. In 1885, the German stratigrapher Melchior Neumayr replaced these mythical bodies of water with one whose former existence was firmly based on the distribution of marine deposits of Jurassic age (Fig. 1). His father-in-law, the great Austrian geologist Eduard Suess, pointed out in 1893 that this Jurassic marine realm had been in fact an ocean, whose compressional obliteration between the northern Angara-Land and the southern Gondwana-Land had generated the Alpine-Himalaya mountain chains. To underline its oceanic character, Suess called this sea Tethys, the sister and wife of Okeanos, the god of the ocean in Greck mythology. In 1895, Suess further pointed out that the age of Tethys had extended down into the Triassic.

The notion of Tethys turned out to be one of the most important and durable concepts that modern geology has inherited. However, its importance and durability have been largely due to its tremendous variability developed during the first quarter of our century. Following Neumayr's lead, paleo-biogeographers declared it an equatorial seaway from Central America to Southeast Asia with a distinct faurat (Fig. 2A). For stratigraphers Tethys implied a certain col-

Figure 1: Melchior Neumayr's Jurassic seaway (Zentrales Mittelmeer), which later formed the basis upon which suess built his Tethys concept. From Neumayr (1887).

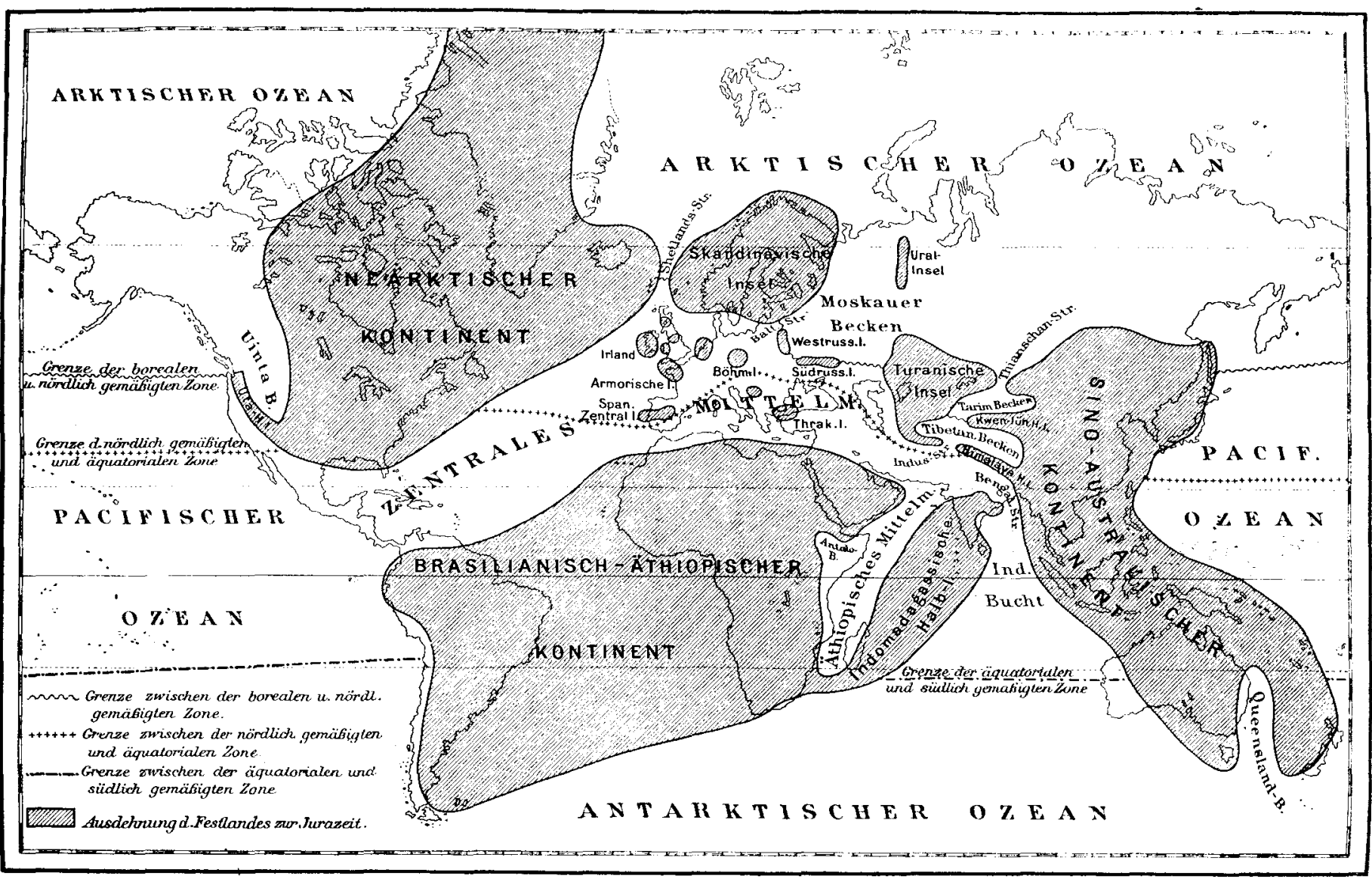


lection of mainly Mesozoic marine facies realms. Tectonicians were divided into two camps in regard to Tethys. Some considered it a "fixed" geosyncline that had existed since the later Proterozoic and that had diminished in size progressively throughout the Phanerozoic and eliminated finally during the "Alpine orogeny" (Fig. 2B), while others saw it as a rather narrow "mobile" marine realm caught up between the drifting continental rafts of Laurasia and Gondwana-Land (Fig. 2C).

All these diverse, even incompatible views had one attribute in common that they had inherited from Neumayr and Suess: they all regarded Tethys as a single feature. Whether an epicontinental seaway, or an ocean, or a geosyncline, it was believed to have been one narrow marine realm bordered by two major continental masses.

When Wilson reconstructed the Permo-Triassic Pangaea in 1963 , he realised that a gap had to open along what is now the Alpine-Himalayan ranges. This triangular feature
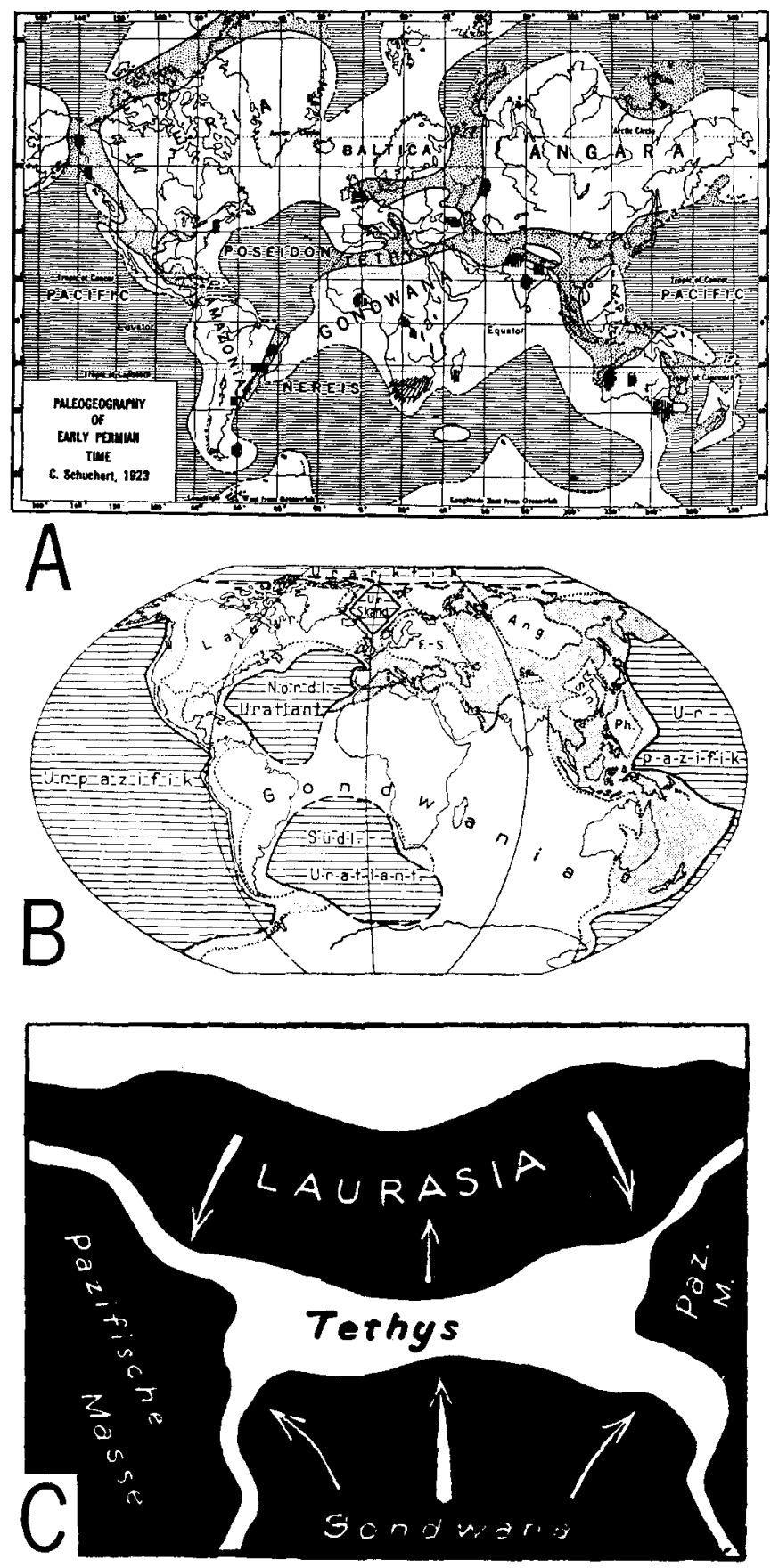

Generalised timing of events along the Tethyside sutures. Suture segments keyed to Figure 4. Along the Cimmeride sutures only times of ocean closure are indicated, whereas along the Alpide sutures both opening (O) and closing (C) times are given.

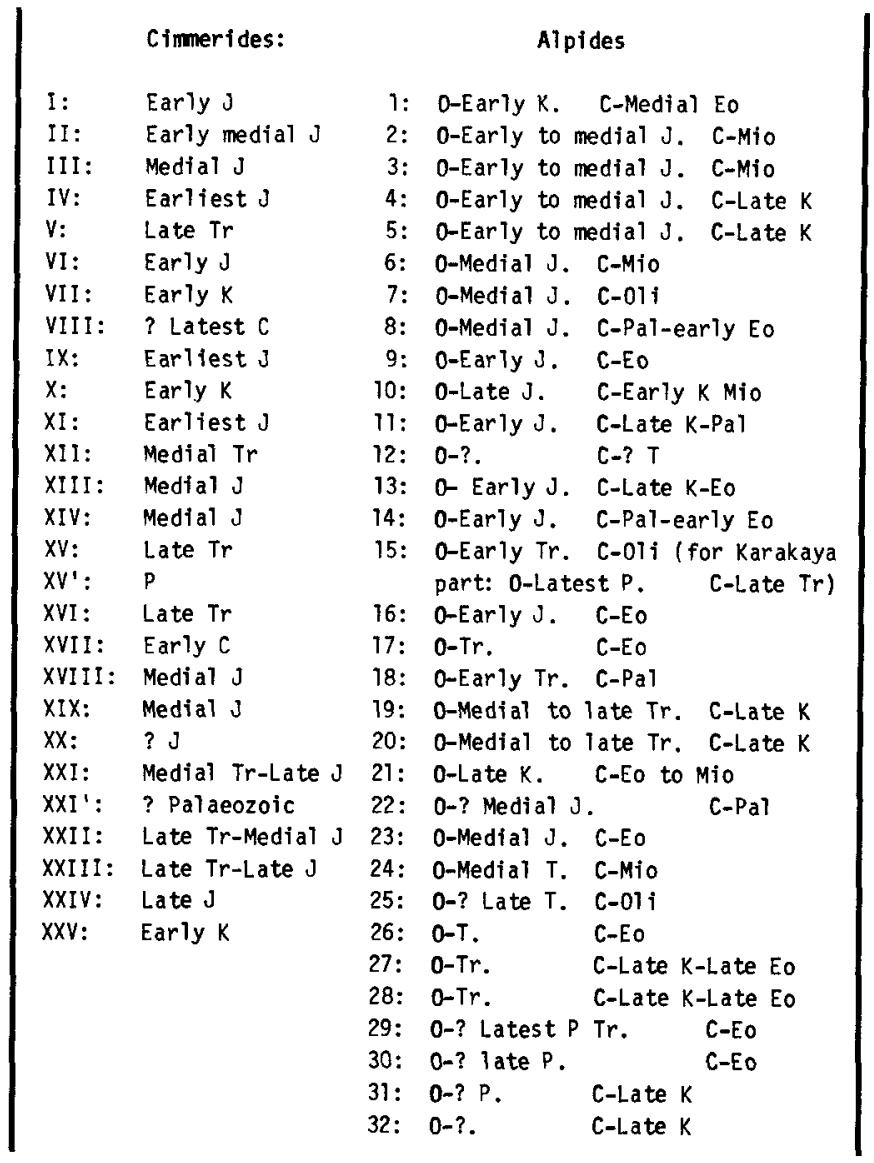

(C -Carboniferous, P - Permian, Tr - Triassic, J - Jurassic, K - Cretaceous, T - Tertiary, Pal - Paleocene, Oli Oligocene, Mio - Miocene, Eo - Eocene)

(Fig. 3A) seemed to provide a resounding confirmation of the existence and the singularity of the Tethys, and its obliteration during the later dispersal of Pangaea, coeval with the growth of the Alpine-Himalayan orogenic system, was hailed as one of the great predictive successes of the theory of plate tectonics (Dietz and Holden, 1970).

Already in 1971, however, Alan Smith knew that the story of Tethys was not as straightforward as geologists had been led to believe, for he had in vain searched for vestiges of the Permo-Triassic oceanic gap in the Alpine System, i.e. the Mesozoic-Cenozoic orogenic belts around the Mediterranean Sea! While continental reconstructions demanded a fairly wide Tethys during Permo-Triassic time, field evidence from the circum-Mediterranean regions appeared to indicate consistently that no Tethys could have existed prior to the medial Triassic (Smith, 1973).

There seemed to be three ways out of Smith's dilemma. The first was to question the validity of plate tectonies, but the weight of the corroborative evidence from everywhere else

Figure 2: Early 20th century variations on Tethys: A - a palaeo-biogeographer's vision of Tethys in Permian time (Schuchert, 1928); B - a fixist view (Stille, 1949); C - a mobilist view (Staub, 1928). 
has since made this an unfruitful line of attack. The second possibility, that the reconstructions themselves may have been erroneous, has been explored by various workers (e.g. Fig. 3B). Smith himself proposed one such revision (Fig. 3C) in which the Pangaean embayment is largely absent but where there are many inconsistencies in the western part of Pangaea. The most recent consensus seems to favour again a Pangaean geometry very similar to that which had originally appeared incompatible with the field evidence (Van der Voo et al., 1984). The resulting desperation has pushed such authors as Stöcklin (1983) and Owen (1983) to consider expanding Earth models (Fig. 3D). These are, however, generally viewed as unlikely for sundry reasons (cf. Hallam, 1984a).

The third and perhaps the most unsophisticated possibility was to consider the adduced field evidence insufficient to discuss whether there really was a Tethyan dilemma. Many authors who regard the paradox as real tend to overlook the fact that it has been based entirely on negative evidence, i.e. on the absence of indicators of a Permo-Triassic ocean in areas where regional geological work is still at a reconnaissance stage and from where the results of existing studies only irregularly reach the international audience.

In the following section I review the present suture distribution in, and the evolution of the Alpine-Himalayan system to show the existence of the Permo-Triassic Pangaean embayment from about the Balkan Peninsula eastwards. This
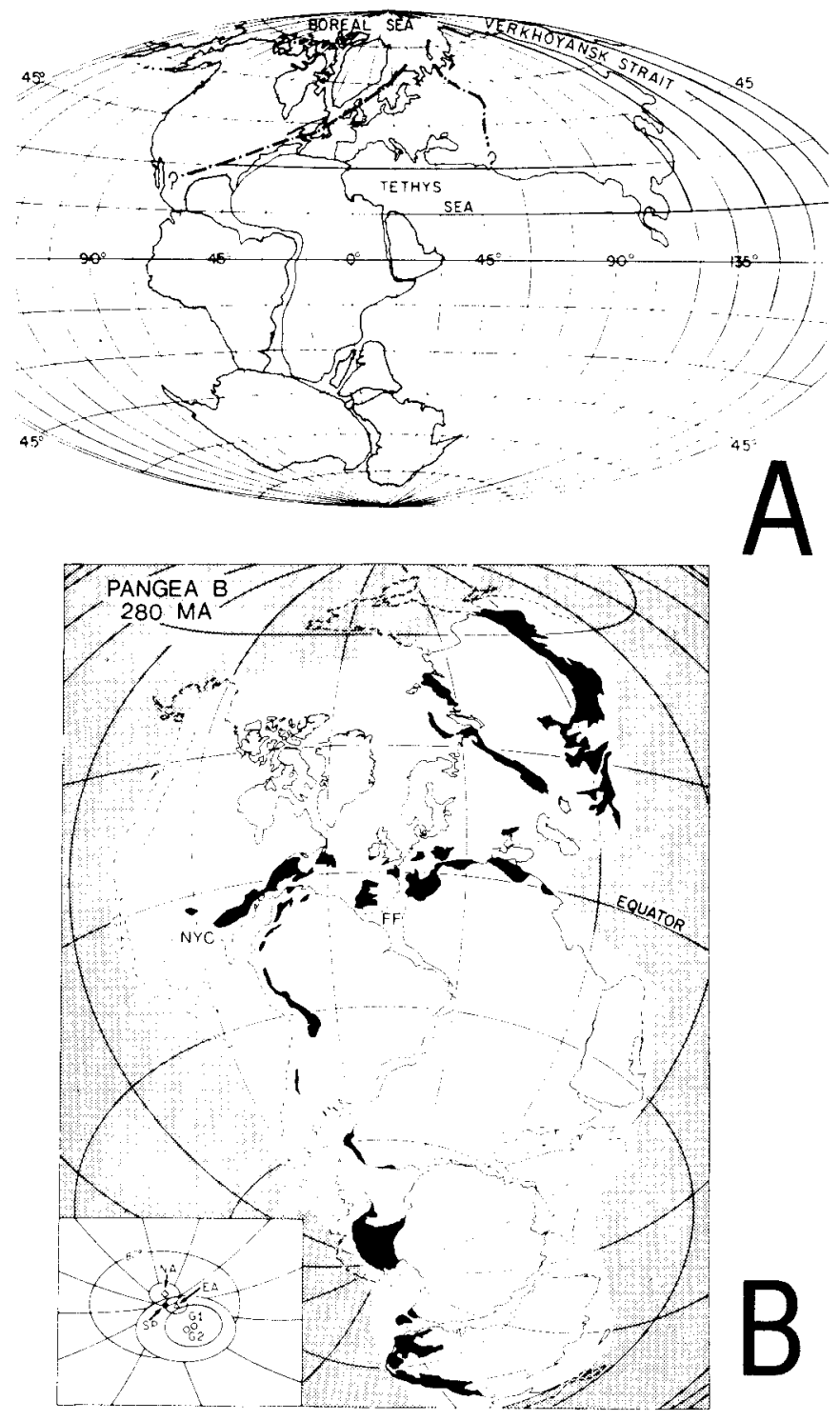

Episodes, Vol. 8, No. 1, March 1985 appears to have closed concurrently with the opening of the ocean that has been traditionally regarded as the Tethys. Although the data on which the iollowing discussions are based cannot be documented here, there are detailed discussions and a rich listing of the relevant literature in Belov (1981), Klimetz (1983), Khain (1984), Şengör (1984, in press), Zhang et al. (1984), Sengör and Hsü (in press), Sengör et al. (1985), Savostin et al. (in press), and Westphal et al. (in press).

\section{Tethyan Blocks, Sutures, and Orogens}

Smith's dilemma originally arose because the suture zones that he and his followers considered in the Alpine System had proved to represent entirely post-Palaeozoic oceans, i.e. the Tethys in the classical sense (Table 1). Sengör (1984) termed Alpides the orogenic belts that had grown out of the "classical" Tethys. Figure 4 shows the distribution of the Alpide sutures in the Alpine-Himalayan mountain ranges as a whole, those in the Alpine System forming a small subset.

Figure 4 also shows another set of sutures located generally north of and parallel with the Alpide sutures. Sengör (1984; in press) showed that ocean closure along this set of sutures occurred largely during late Triassic to medial Jurassic time

Figure 3: Plate tectonic variations on Tethys: Athe triangular Pangaean embayment of Wilson (1963); $B$ - Morel and Irving's (1981) "Pangaed $B^{\prime \prime}$ that reduces the size of the embayment considerably; $C$ - the end-Palaeozoic Pangaea of Smith and others (1981), D-Owen's (1983) reconstruction for 180-200 Ma on a base $80 \%$ of the modern diameter of the Earth.
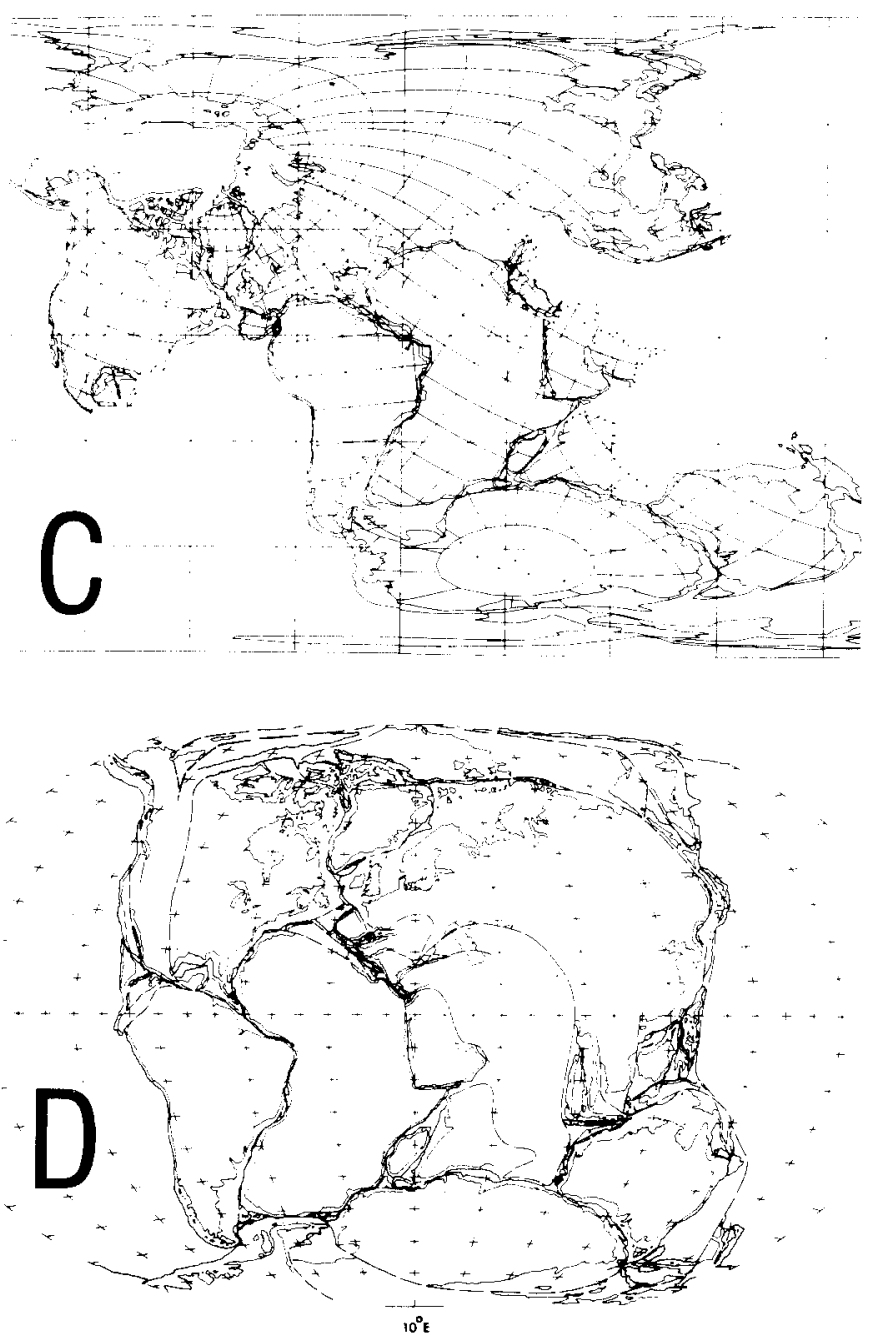
Figure 4: Distribution of the Tethyside sutures and blocks. The non-Tethyan late Palaeozoic sutures in Europe ("Hercynides") and in Asia ("Altaids") are shown to illustrate their complete independence from the Tethysides (possibly except the South Ghissar suture shown by G). $Z$ northern boundary suture of North China block according to Zhang et al. (1984). E - East Anatolian accretionary complex. $M$ - Makran accretionary complex. $S$ - Songpan-Ganzi System. For timing of events along the Tethyside sutures, see Table I. Modified and updated System. For timing

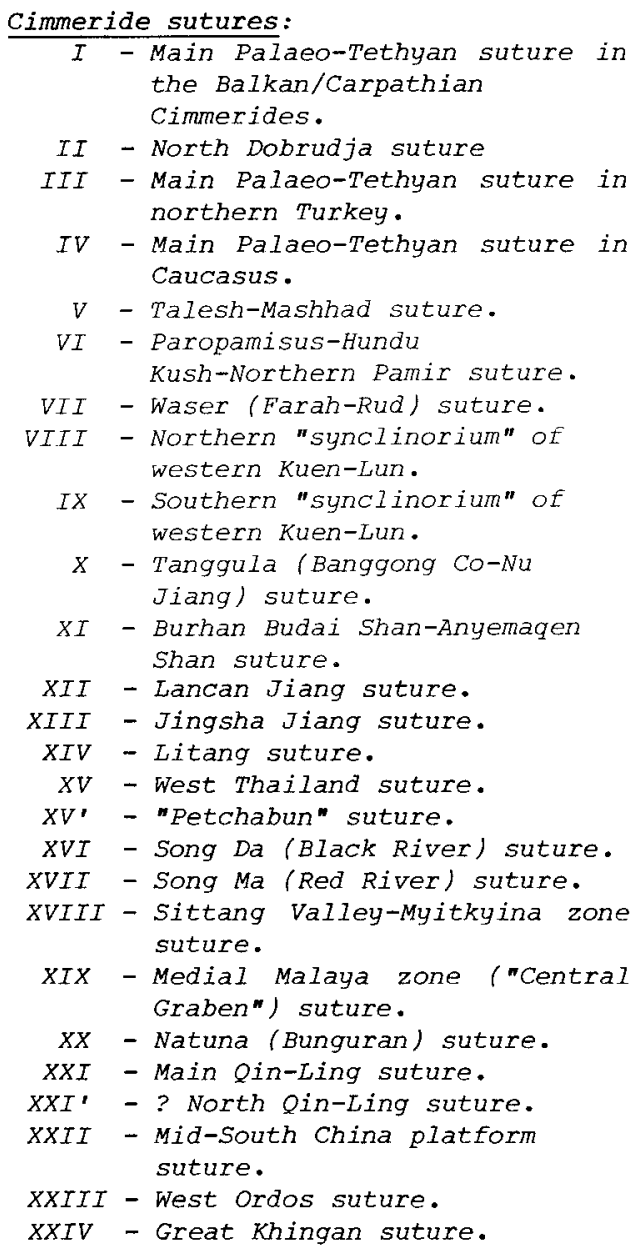

$X X V$ - Shilka zone suture.

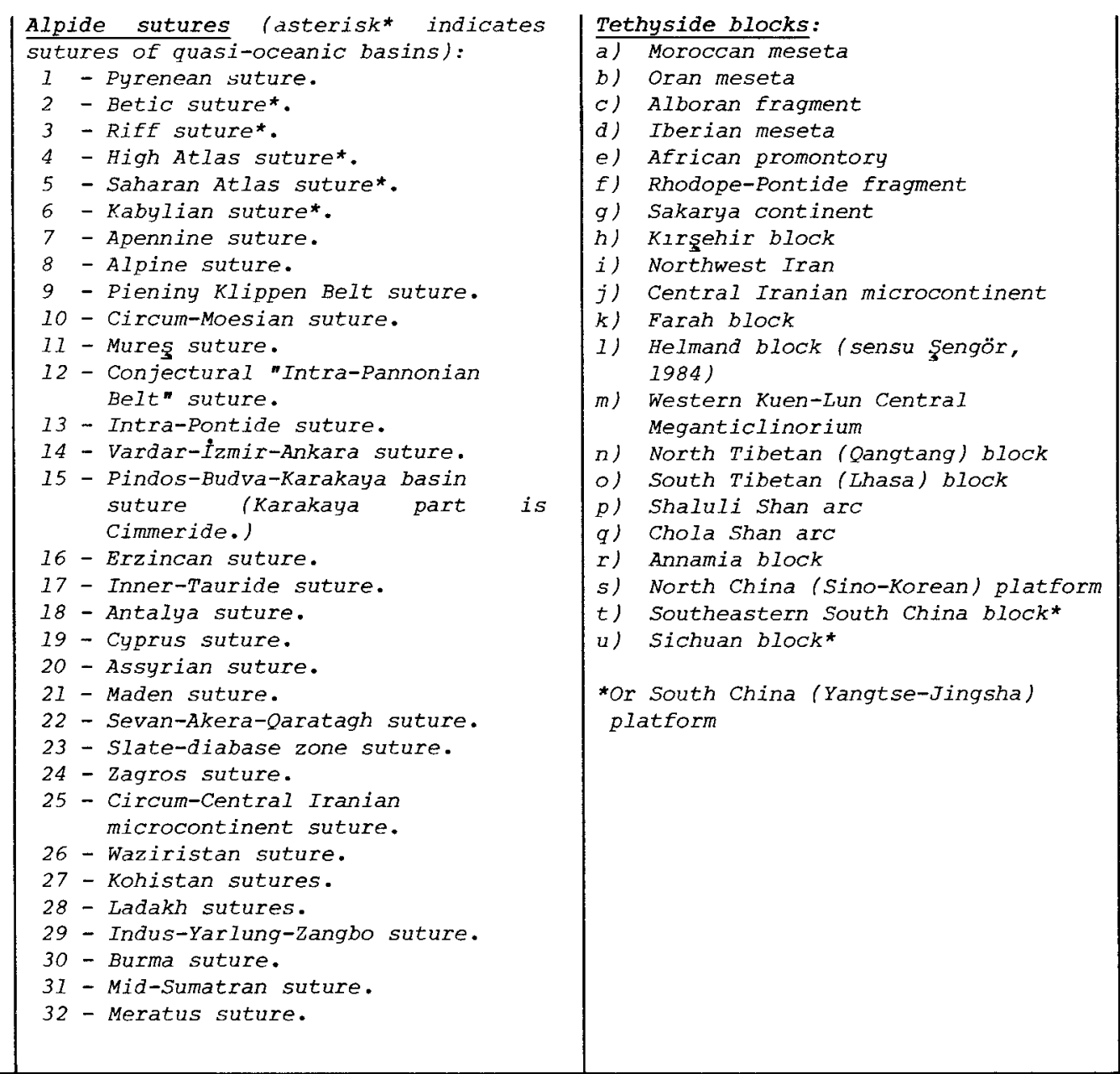

$$
\mid
$$




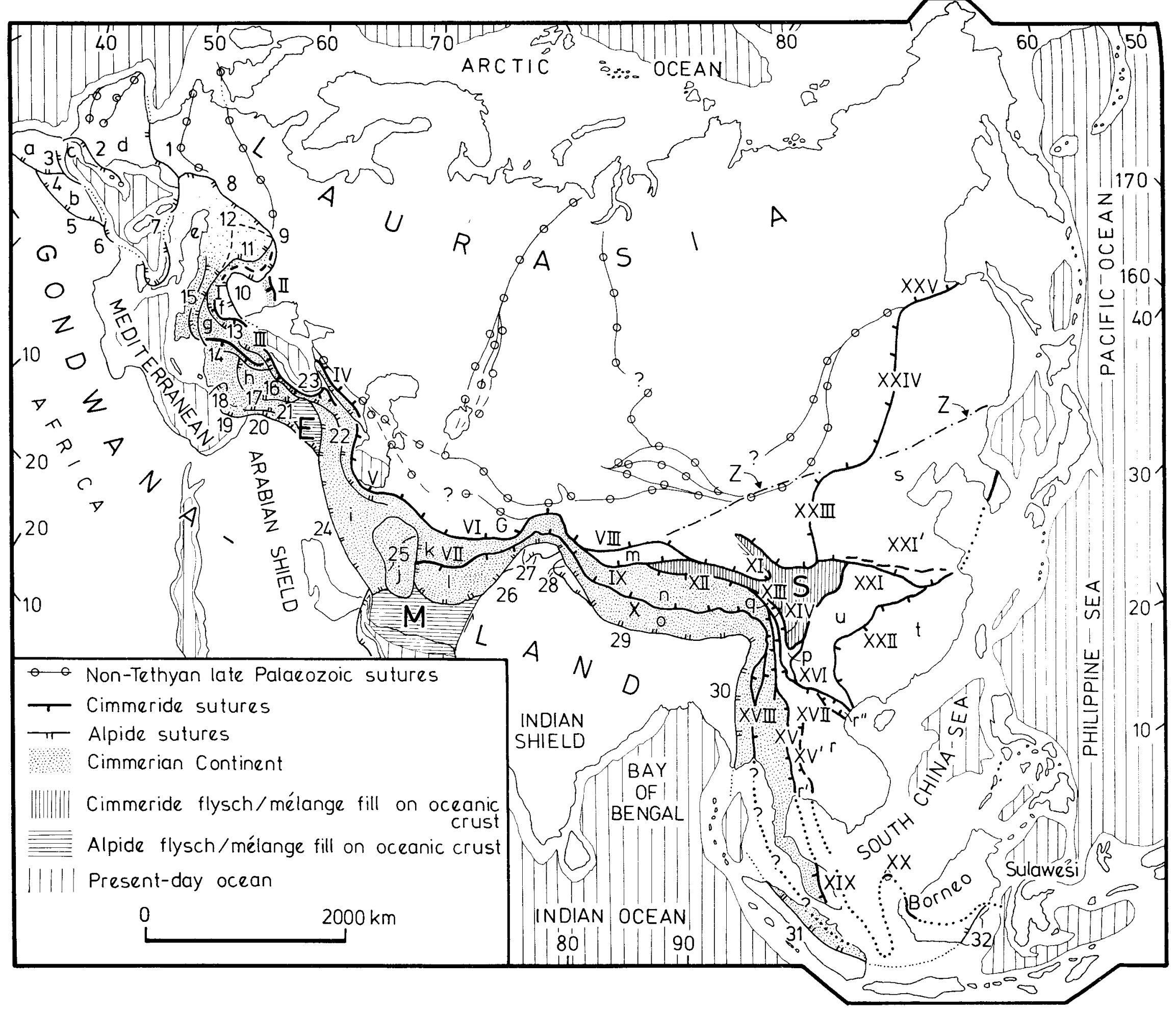




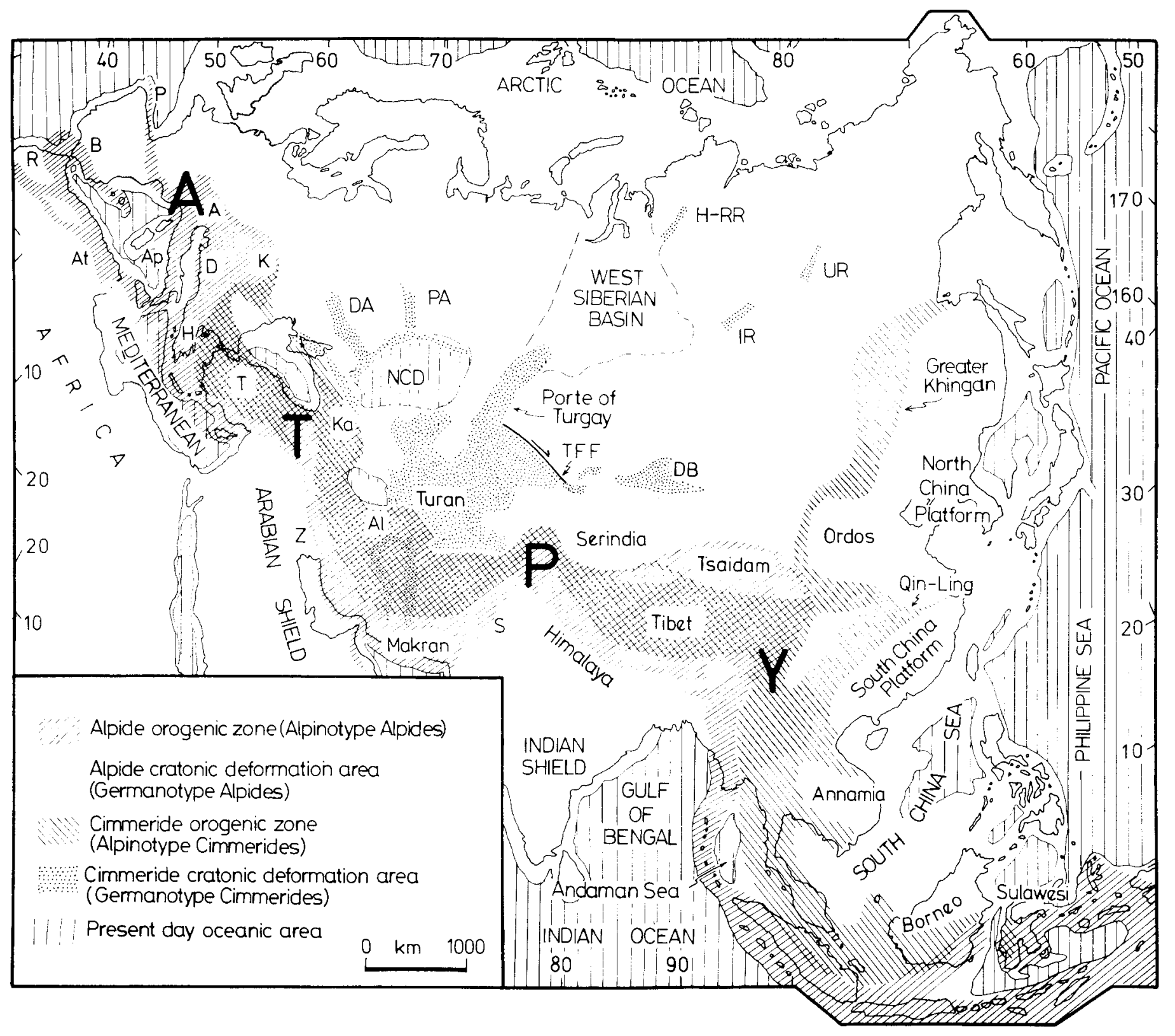

Figure 5: Areal extent of the Tethyside "super orogenic complex" consisting of the Cimmeride and Alpide orogenic zones and the areas of cratonic disruption associated with each (Modified after Sengör, 1984). Key to the smaller letters: $A=$ Alps, $A 1=$ Alborz, $A p=$ Apennines, $A t=$ Atlas, $B=$ Betics, $C=$ Carpathians, $C a=$ Caucasus, $D=$ Dinarides, $D A=$ Donetz aulacogen, $D B=$ Junggar basin, $H=$ Hellenides, $H-R R=$ Hantaj-Rybninsk Rift, $I R=$ Irkineev Rift, $N C D=$ North Caspian Depression, $P=$ Pyrenees, $P A=$ Pachelma aulacogen, $R=$ Riff, $S=$ Suleiman ranges, $T=$ Turkish ranges, TFF Talasso-Fergana fault, and $Z$ = Zagros. Key to the larger letters: $A=$ Alpine syntaxis, $T=$ Turkish syntaxis, $P=$ Pamir syntaxis, $T=$ Yunnan syntaxis.

(Table I) and generated a multi-branched orogenic system that was entirely independent of, but widely overprinted by the Alpides, thus making its recognition extremely difficult. This early to medial Mesozoic orogenic belt Şengör (1984) named the Cimmerides, after the Cimmerii, the oldest known inhabitants of the northwestern shores of the Black Sea where evidence for Cimmeride orogenic events had been first discovered (Suess, 1909, p. 22). Figure 5 shows the areal extent of the Cimmeride and Alpide orogenic systems, together constituting the "super orogenic complex" Tethysides (Şengör, 1984). It has thus become apparent that the Alpine-Himalayan mountain ranges are actually formed from two different, but largely superimposed orogenic systems that resulted from two independent groups of ocean closure events (Table 1).

The Alpides are the products of the convergence and final collision with Eurasia of independent pieces of the dispersed Gondwana-Land, such as Afro-Arabia and India (cf. Savostin et al., in press; Westphal et al., in press). Likewise, the Cimmerides seem to have been generated by the collision, with Eurasia also, of two groups of continental objects. One of these between the Balkans and Malaysia (stippled in Fig. 4) was dominated by a long and evidently not very wide continental stripe that rifted from the northern margin of Gondwana-Land during the latest Palaeozoic-earliest Mesozoic and united with Eurasia during the late Triassicmedial Jurassic interval (Table 1). This Cimmerian Continent (Sengör, 1979) further distintegrated as it moved across the Tethyan domain - but without disrupting its east-west continuity (Fig. 6A-C)! 
Some of the oceans that formed during its disintegration remained entirely inside the Cimmerian Continent, whereas others became branches of the ocean that opened behind it. Şengör (1979) called the ocean that closed north ("in front") of the Cimmerian Continent Palaeo-Tethys, which he identified with the original Permo-Triassic Pangaean embayment. The ocean that formed between the Cimmerian Continent and Gondwana-Land (i.e. "behind" the Cimmerian Continent) he called Neo-Tethys, which corresponds with the "classical" Tethys.

The second group of continental blocks that collided with Eurasia and the Cimmerian Continent to eliminate PalaeoTethys was located east of the $100^{\circ} \mathrm{E}$ meridian and consisted of three major pieces: the North ("Sino-Korean") and South ("Yangtse") China platforms, the Indochina ("Annamia") block, and a number of other smaller blocks (Fig. 4; Şengör

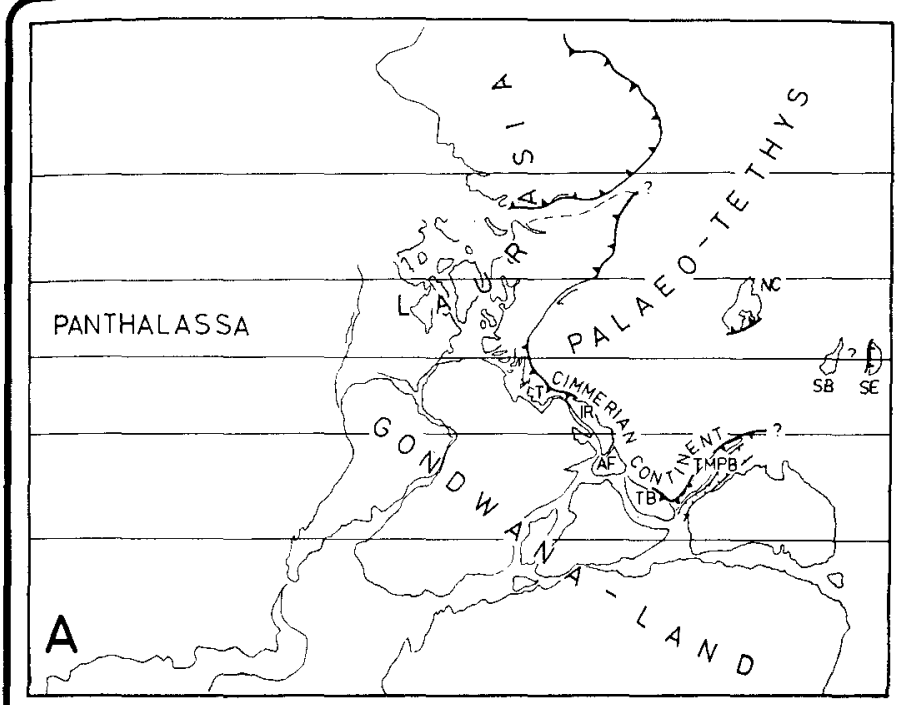

A Late Permian geometry. $T$ - Turkey, IR - Iran, AF - Afghanistan, $T B$ - Tibet, TMPB - Thai-Malayan Peninsula block, NC - North China block, SB - Sichuan block, SE - SE China block.

$\underline{B}$ - Latest Triassic (Rhaetian) geometry. A Annamia block, AG - AkgöI flysch basin, $F$ - Farah block, H - Helmand block (sensu Şengör, 1984). NTB and STB - North and South Tibetan blocks, A Annamia, SG - Songpan-Ganzi System.

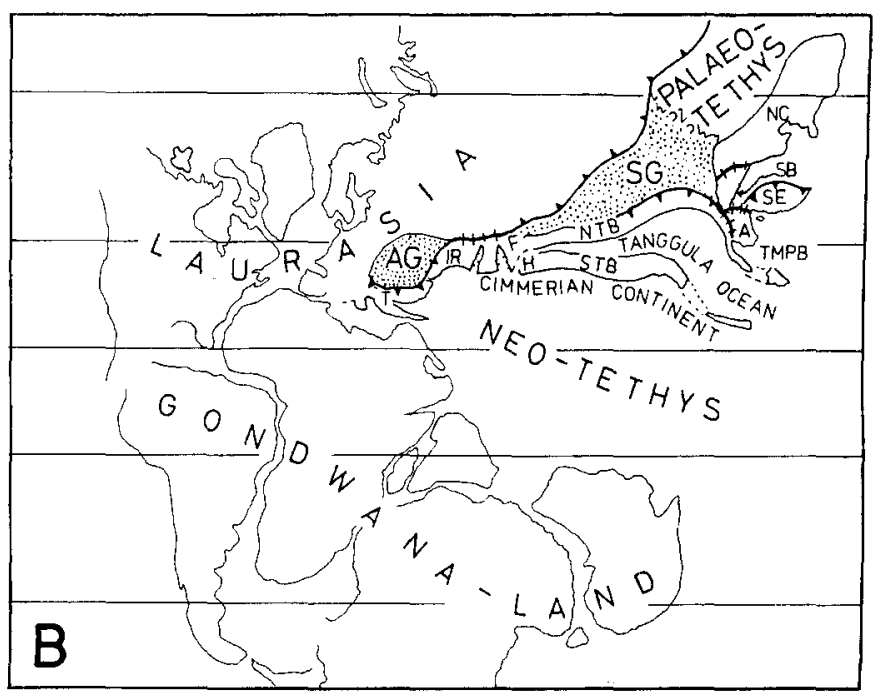

and Hsü, in press). Although no unequivocal evidence now exists to identify the provenance of these blocks, it is strongly suspected that they may have parted from Gondwana-Land before the Carboniferous.

All of the continental blocks that now lie welded to each other within the Tethysides (Fig. 4) constitute the Cimmeride orogenic collage (Şengör, 1984). The accretionary history of this collage around the southern fringe of Eurasia makes up the story of the demise of Palaeo- and the birth of Neo-Tethys.

History of Accretion of the Cimmeride Orogenic Collage

The story of the demise of Palaeo-Tethys and the growth of the Cimmeride orogenic system properly begins with the onset of the subductive removal of the floor of the former. There is evidence that much of that subduction had actually

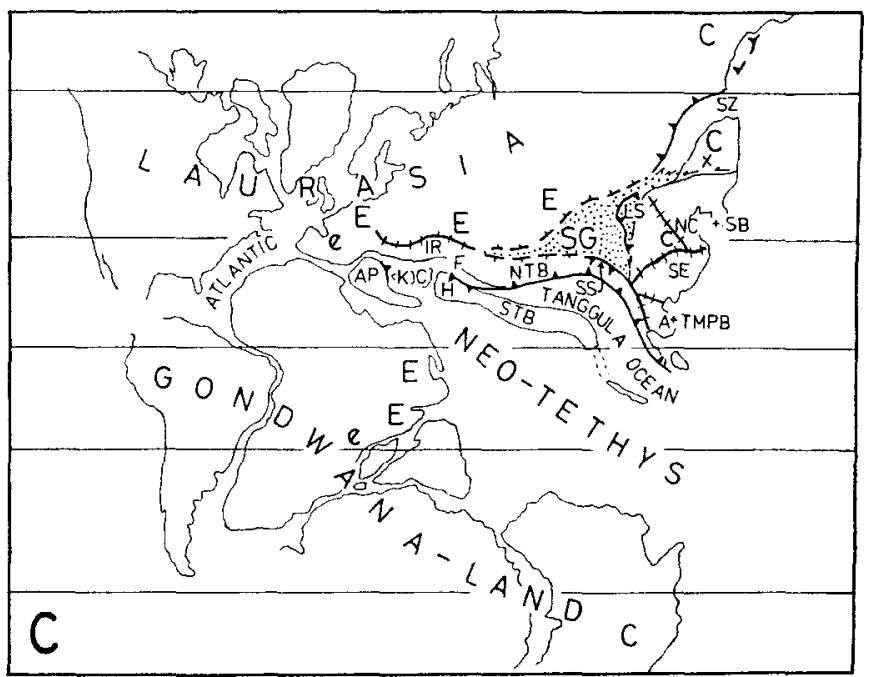

C - Medial to late Jurassic geometry. AP - Apulian platform (- African promontory), K - Kirşehir block, C - Central Iranian Microcontinent, LS - Longman Shan block, X - Xiliao-He Fault, SS - Shaluli Shan arc, SZ - Shilka zone, C - Coal, E,e - major and minor evaporites.

$D$ - Early Cretaceous geometry. C,C - major and minor coal occurrences, $B$ - bauxite, I - ironstones.

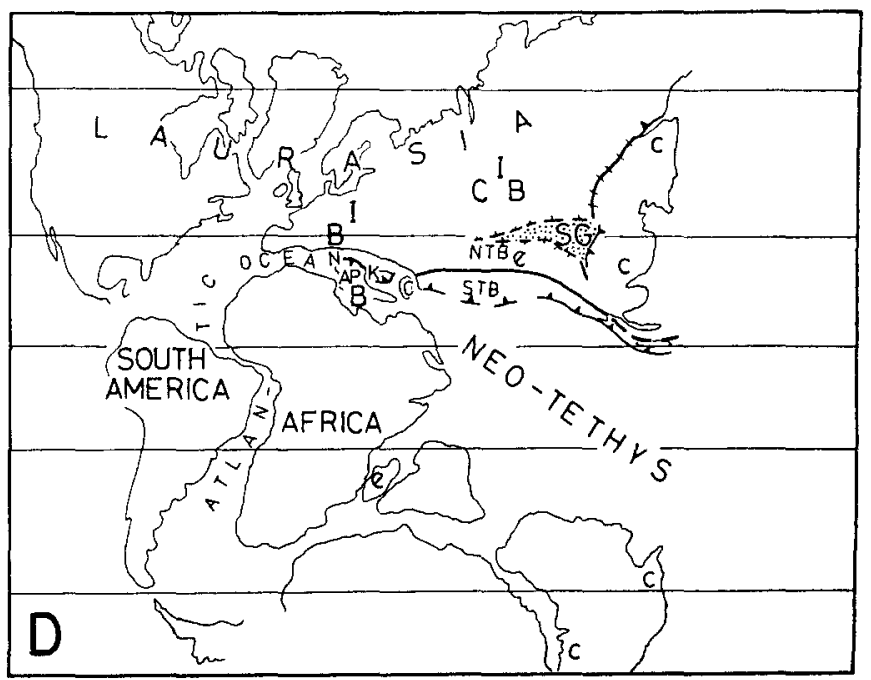

Figure 6: Tectonic evolution of the Tethysides between the 1ate Permian (Kazanian) and the medial Cretaceous. Modified after Sengör and Hsii (in press); climatically sensitive lithologies added from Hallam $(1984 \mathrm{~b})$. 


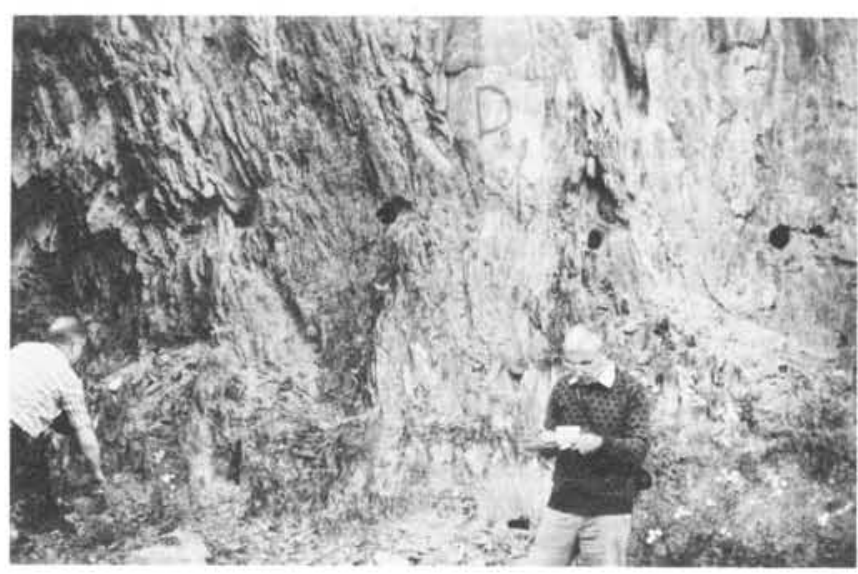

Figure 7: Deformed Devonian clastics ("Dizi Series") along the Inguri Valley in the svanetia region of the southern slope of the Greater Caucasus. These rocks and represent the northernmost outcrop of the cimmerian continent in the Caucasus. The deformation is post-Triassic in age and is interpreted to have occurred during the closure of Palaeo-Tethys (Photo: A.M.C. Şengör).

begun locally both along the southern and northern margins of the future Palaeo-Tethys, even before it formed by the latest Carboniferous assembly of the supercontinent. Subduction toward Gondwana-Land began in northern Turkey in Westphalian B time, whereas in Thailand it was earliest Tournaisian, both cases evidenced by the beginning of arc-type magmatic activity. Subduction toward Laurasia began during the medial Carboniferous along a line stretching from the Paropamisus (VI in Fig. 4) all the way to northern Kuen-Lun (VIII).

These events have been known for at least a quarter of a century, but so far they have been viewed as "Hercynian" events and their relationships with Tethyan evolution have been overlooked (Khain, 1984). By the end of the Carboniferous only the small continental fragment known as the "Central Meganticlinorium of western Kuen-Lun" ( $m$ in Fig. 4) had already collided with Eurasia. Also during Carboniferous time Annamia acquired a collar of collisional orogens by the docking against it of two island ares along the sutures XVII and XV'.

Rifting associated with the beginning of the separation of the Cimmerian Continent from northern Gondwana-Land commenced by local normal faulting (as in the Kuh-e Dinar area in the Zagros) and voluminous basaltic eruptions (as in the case of the Panjal Trap in Kashmir) during the Permian (Fig. $6 \mathrm{~A}$ ), but actual continental separation probably took place diachronously from east to west during the earliest (in the Himalaya) to medial Triassic time (in Turkey). Also during the earliest Triassic (possibly already during the latest Permian) the Cimmerian Continent split longitudinally from central-south Afghanistan all the way to Burma to open the Tanggula-Waşer ocean (Fig. 6B). Later, during the medial to latest Jurassic interval this intra-Cimmerian Continent ocean closed along a line that extends from the Farah-Rud zone in Afghanistan (Blaise et al., 1978), through the Banggong CoNu Jiang suture in central Tibet (Sengör, 1981; Girardeau et al., 1984), to the Sittang Valley/Myitkyina Zone orogen in Burma (Mitchell, 1981).

The original shape of the Cimmerian Continent (and/or the southern margin of Eurasia) must have been rather irregular, for the earliest collisional contact it established with Eurasia was in northern Iran, along the Talesh-Mashhad suture (V), during the late Triassic. As seen in Figure $6 \mathrm{~B}$, this collision probably also resulted in the splitting of the Cimmerian Continent in Iran along two rifts at high angles to the
Cimmeride suture. As indicated in Figure $6 \mathrm{C}$, these rifts later spread to isolate a "Central Iranian microcontinent" (the Lut Block of Stöcklin, 1974).

Between Iran and the Balkans, Palaeo-Tethys closed in earliest Jurassic time in the Caucasus along what is now a rather cryptic suture (IV; Fig. 7), and during medial Jurassic time in Turkey (III; Fig. 8), Bulgaria, northern Greece, and possibly Yugoslavia (I). The earliest medial Jurassic suture in the North Dobrudja (II) is believed to be a later displaced fragment of the north Turkish Cimmeride suture (Şengör et al., 1985).

Before the final closure of Palaeo-Tethys, two opening events, which formed back-are basins, successively perforated the bulk of the Cimmerian Continent in the eastern Mediterranean area. The first one opened during the latest Permian-earliest Triassic interval along the Pindos-BudvaKarakaya suture trace (15 in Fig. 4). This event produced what is thought to be a small ocean basin, whose eastern half closed by latest Triassic time (Şengör et al., 1985), whereas the Pindos-Budva segment survived until the early Cenozoic (Table 1). The second opening produced a multi-branched ocean $(13,14,16,17)$ that became the northern branch of Neo-Tethys in the Mediterranean region (Şengör et al., 1985; Şengör, in press).

East of Iran, collision along the Paropamisus - Northern Pamir (VI) - Southern Kuen-Lun (IX) - Burhan Budai Shan (XI) suture systems occurred largely during early Jurassic time as evidenced by the termination of marine conditions and strong orogenic deformation, and by the onset of widespread molasse sedimentation. In these regions intra-continental convergence continued after the collision as shown by the Jurassic compressional structures and persistent topographic highs along the suture zone until early Cretaceous time. Hallam (1984b) recently argued that the "anomalous" late Jurassic arid belt of western and central Asia may have developed in the rain shadow of the Cimmeride mountains that rimmed the southern periphery of Eurasia at the time, when monsoonal winds possibly had a more dominant role than today (Fig. 6C).

As far east as the Burhan Budai Shan, the main trunk of the Cimmeridge orogenic system shows south-facing orogenic polarity. East of the $92^{\circ} \mathrm{E}$ meridian, a north- and then east-facing orogenic wing developed on the northern and eastern margin of the Cimmerian Continent south of the south-facing wing, thus making the Cimmeride orogen twosided, much like the British Caledonides (Fig. 4).

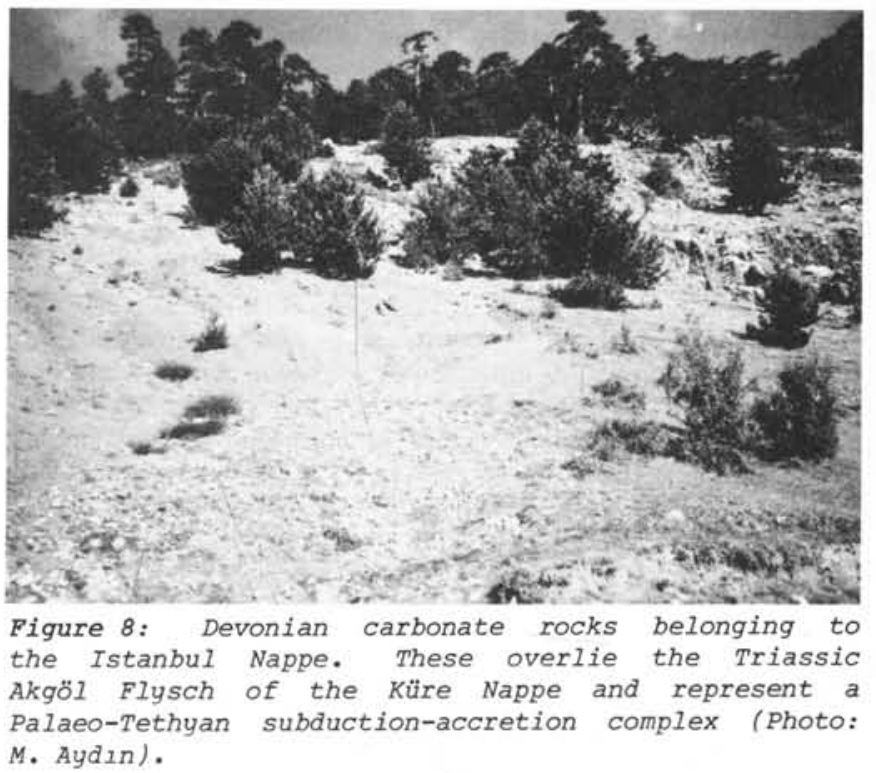


East of the $100^{\circ} \mathrm{E}$ meridian, the Cimmeride orogenic collage suddenly becomes very much enlarged and includes the large continental blocks of North and South China and Annamia, together with a number of other, smaller, much less wellknown continental objects and the flysch and mélange-filled Songpan-Ganzi System of China ( $\mathrm{S}$ in Fig. 4). The history of the suture zones XV, XVI, and XXI shows that they had formed already by latest Triassic time and had welded the three major continental blocks of the eastern Cimmeride collage onto the Cimmerian Continent, thus forming a very long appendage to it. Between this long, composite collage that stood offshore and the main bulk of Eurasia, only a narrow remnant of the original Palaeo-Tethys had remained during the late Triassic.

This remnant was filled with accretionary mélange and flysch complexes, much like those of the present Makran ( $M$ in Fig. 4; Farhoudi and Karig, 1977) and Alaska (Dickinson and Seely, 1979), and whose own remnants are now seen in the Songpan-Ganzi System of China (Şengör, 1981) (Fig. 4). As seen in Figure 6B, this accretionary fill formed a virtual land area between the "offshore" collage and the mainland and enabled a number of land vertebrates of Laurasian affinities to cross over to Southeast Asia during the late Triassic and Jurassic time (Buffetaut, 1981).

Continued convergence of the collage and the main continent further tightened and deformed the accretionary fill, beneath which ocean floor subduction was continuing to accommodate the ongoing convergence, albeit in a "hidden" fashion (cf. Sengör, 1984) under the peripheral arcs of the Songpan-Ganzi System until the early Cretaceous (Fig. 6D) (Sengör and Hsü, in press). Palaeomagnetic evidence shows that the tightening of the suture zones and the Songpan-Ganzi System, presumably by the constriction of the original flysch and mélange fill, resulted in a $1650 \pm 750 \mathrm{~km}$ northward motion of Annamia and South China during the Jurassic (Achache, 1984).

Finally, during the latest Jurassic-earliest Cretaceous time, the formation of the Cimmeride orogenic System and the elimination of Palaeo-Tethys, were completed by the closure of the Shilka suture (XXV: for a different view of the tectonies of northeastern China see Zhang et al., 1984) and the elimination of the Tanggula-Waser ocean. During the early Cretaceous (locally already during the Jurassic in the Hellenides and in Ladakh), north-directed subduction of NeoTethyan ocean floor commenced all along the southern periphery of the former Cimmerian Continent and thus initiated the Alpide growth on the ruins of the Cimmerides. The story of the demise of Neo-Tethys as a partial compensation of the opening of the Atlantic and the Indian oceans is rather too well known to be repeated here.

\section{Conclusions and Discussion}

A review of the available field evidence from the entire Alpine-Himalayan mountain ranges shows that during early and medial Mesozoic time the Tethyan domain consisted of two independent oceanic realms separated by a continental strip, or perhaps an archipelago, called the Cimmerian Continent. This began rifting from northern Gondwana-Land mainly during Triassic time. In the early Triassic-medial Jurassic interval, it rotated counterclockwise around the western apex of the triangular embayment of the Pangaea, the Palaeo-Tethys. This rotation progressively eliminated the Palaeo-Tethys and opened, in the wake of the Cimmerian Continent, Neo-Tethys, which is identical with the "classical" Tethys of Suess.

The elimination of Palaeo-Tethys, by the collision with Eurasia not only of the Cimmerian Continent, but also of a large orogenic collage that had mostly accreted around its eastern end, formed the large, multi-branched orogenic complex of the Cimmerides. In contrast the closure of NeoTethys generated the Alpides, largely on the ruins of the Cimmerides. This overprinting is one of the main reasons why the recognition of the Cimmerides as an entirely independent Tethyan orogenic system has been so difficult.

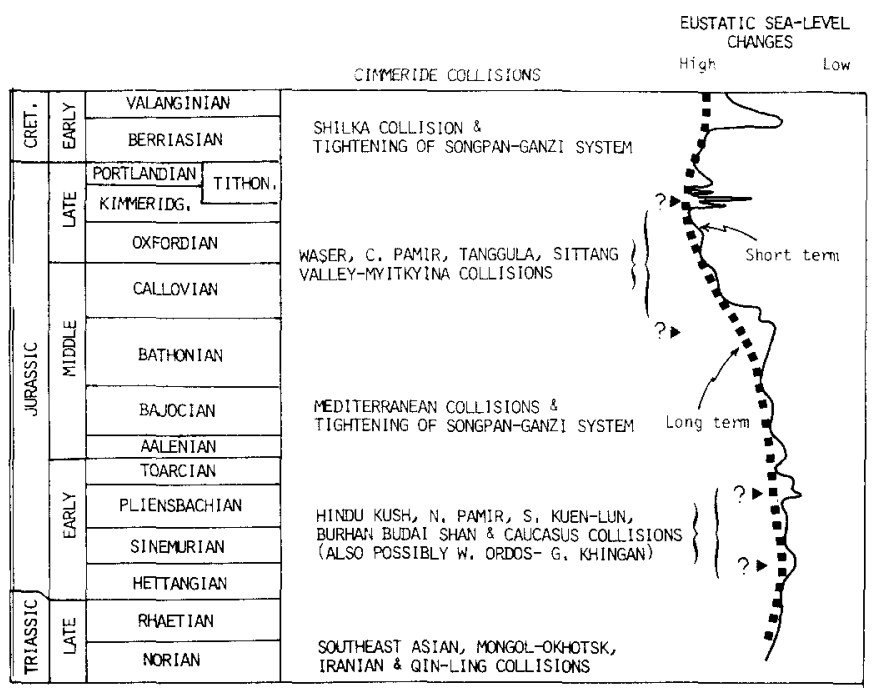

Figure 9: Late Triassic to early Cretaceous worldwide eustatic sea-level changes (after vail et al., in press) correlated with the major Cimmeride collisions.

Another reason for the late recognition of the Cimmeride orogenic system was that the Cimmeride events that had taken place during the late Palaeozoic and the Triassic have so far been viewed as "Hercynian" events, whereas those that occurred during the Jurassic and the early Cretaceous have been lumped into the "Alpine" orogenic cycle. Thus, the traditional tri-partite subdivision of all terrestrial Phanerozoic orogenic phenomena into "Caledonian", "Hercynian", and "Alpine" cycles has resulted in an artificial splitting of related events in the Tethyan realm (and in most other places as well) into different groups, thus hindering their correct recognition.

Ironically, although the three-fold grouping of Phanerozoic orogenic events is a left-over from the long-abandoned contraction theory, its phase terminology and the associated temporal pigeon-holes still enjoy a healthy existence. They are of ten encountered in plate tectonic-based publications as, for instance, in the case of the Banggong Co- $\mathrm{Nu}$ Jiang suture promptly dubbed as "Neo-Cimmerian" (Girardeau et al., 1984)! I believe that the time has come to realise that the entire phase terminology was based not on observations, but on their interpretation according to a model, which is incompatible with the behaviour of our planet as it is currently understood. Further use of this terminology is misleading and may lead to very serious misinterpretations in regional geological studies, as the example of the Cimmerides has shown.

An interesting effect produced by both Cimmeride and Alpide orogenic events (both collisional and non-collisional) is the widespread cratonic deformation in Eurasia. These cratonic structures are large strike-slip faults of diverse orientations, graben complexes that trend at high angles to the orogen and ramp valley basins that trend sub-parallel with it. Molnar and Tapponnier have described such structures developed during Alpide collisions (see Tapponnier et al., in press, for a review). Şengör (1984) has shown that a very similar set of structures also formed during the Cimmeride evolution.

The best-known members of these are the early Mesozoic folded belt of the Donetz (inverted aulacogen), the Porte of Turgay graben complex and its northerly prolongation in the southern part of the West Siberian Basin, the Junggar basin, and the Talasso-Fergana fault (Fig. 5). As Şengör (1984) has shown, a very large number of the "inversions" of former rifts in Eurasia was nothing more than their compression across strike as parts of much wider cratonic fields of deformation 
generated by Cimmeride and Alpide collisions along the southern and southeastern periphery of the continent (Fig. 5). It seems that many of the Cimmeride cratonic structures helped to localise similar structures associated with the Alpide events.

Because in Eurasia, Cimmeride and Alpide deformations were roughly coaxial on a continental scale, this repetition of similar kinds of tectonic events in more-or-less the same places (especially the basins and uplifts) has given the impression that the causes of such what appeared to be "long-lived" phenomena" were located beneath the respective structures and were "fixed" in space. This line of thinking was, I believe, what eventually led to the fixist oscillationist hypotheses (e.g. Beloussov, 1980). The consideration of the "double history" of the Tethysides, as reflected in the evolution of the Cimmerides and the Alpides, shows that the criticism directed by the fixist schools toward plate tectonics, that it does not explain the presence of long-lived intra-cratonic structures in Eurasia, is not valid. Moreover, the explanation plate tectonics offers for these structures is more satisfactory because it obviates the need to resort to ad hoc "endogeneous regimes."

Another interesting aspect is the remarkable correlation of times of major Cimmeride collisions with those of major falls in sea level (Fig. 9). Dewey and Windley (1981) argued that because collision gathers the continental crust into a smaller area, it enlarges the volume of the oceans. Because during collisions subduction zones, which facilitate plate motions, are lost, collisions generally effect a global slow-down of plate motion rates and thus a dimunition of mid-ocean ridge volumes; this also increases the capacity of the ocean basins. Thus, generally, collisions result in regressions.

It appears that the Cimmeride collisions provided at least one possible factor affecting the early and medial Mesozoic sea-level changes. The creation during the early Cretaceous of the long Alpide subduction zone (Fig. 6D) may have been one of the factors that led to the late Cretaceous transgression. The problematic late Jurassic spread of arid conditions into Europe and Central Asia may have been helped along also by the sudden Kimmeridgian sea-level drop that was possibly related to the closure of the Tanngula-Waşer ocean (Fig. 9).

Finally, the evolution of the Tethysides as a whole has disclosed a persistent trend in the evolution of Pangaea since at least the Permian, namely the progressive disintegration of the southern supercontinent and the northerly flight of its dispersed pieces to unite with Eurasia. This tendency "to go north" is also seen in the variety of much smaller blocks that have been accreted to Japan and to the North American Cordillera also since the Permian (Mascle and Marcoux, 1982). This large-scale and persistent migration northwards of continental blocks appears significant and somehow must be related to, and a reflection of, the kinematics of the first-order convective circulation, at least in the upper mantle. If a history of convection in the mantle is ever attempted, the evolution of the Tethyan realm, which forms $1 / 3$ of the planetary diameter, would provide significant constraints for a time period nearly half of the entire duration of the Phanerozoic.

In conclusion, the recognition of the existence of another, older Tethys, (i.e. another "wife" of Okeanos) not only resolves the Tethyan paradox, but also illuminates many other, hitherto less well-understood facets of the tectonics of Eurasia. Although what I have related in the above paragraphs may seem satisfying and fruitful, I wish to underline the fact that it is still based on very few and generalised data that may have led me, as the blind man in the old Indian tale, to describe what in reality is an elephant as a serpent, because so far I may have been able to feel only its trunk. I cannot find a better epilogue for this article than the words with which Suess closed his first essay on the Tethys:

"But all this is unripe fruit. Our scholars will some day know more than their masters do now; so let us patiently continue our work and remain friends."

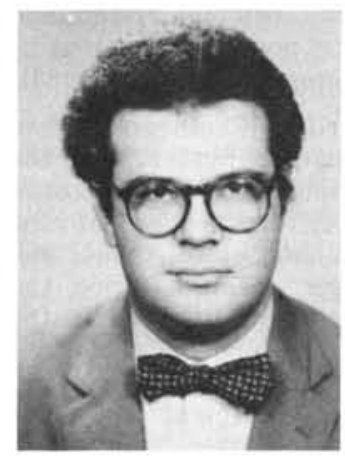

A.M. Celâl Şengör lectures on structural geology and tectonics in the Istanbul Technical University. Regional tectonics, especially of Eurasia, is his principal topic of interest. $\mathrm{He}$ is the author or coauthor of two books and more than 60 papers on tectonics and related subjects.
References

Achache, J., 1984. Paléomagnetisme des zones actives, Croissance, destruction et formation des
marges continentales. Thèse de Doctorst d"Etat, Univ. Paris vit.

Beloussov, V.V., 1980. Geotectonies. Mir Publishers, Moscow, 330p.

Belov, A.A., 1981. Tectonic develogment of the Alpine folded area in Palacozole. Transactions, Academy of Seiences of the U.S.S.R., v. 347, 212p. (in Russian).

Blaise, J., Bordet, P., Carbonnel, J-P. and Montenat,
C., 1978, Flyschs et ophiolites dans is région de Panjaw C., 1978. Flyschs et ophiolites dans la région de Panjaw. une suture néocimmeerienne en Afghanistan central.
Bulletin de la Société géologique de France, je sér., Bulletin de la 20 , D. $795-798$.

Buffetaut, E., 1981. Eléments pour une histoire paléobiogeographique du Sud-Est asiatique l'apport des géologique de France, 7 e sér., v. 23, p. 587-59. Dewey, J.F. and Windley, B., 1981. Growth and
differentiation of the continental crust. Phillosophich Transactions of the Royal Society of London, v. A 301 . p. 189-206. Dickinson, W.R. and Seely, D.R., 1979. Structure and
stratigraphy of forearc regions. Bulletin of the
Amerien Association of Petroleum Geologists, $v, 63$, Amerien. $2-31$.

Dietz, R.S. and Holden, J.C., 1970. Reconstruetion of Pangaeas Breakup and dispersion of continents, Permian to present.
p. 4939-4955.

Farhoudi, G. and Karig, D.E., 1977. Makcran of Iran and Psikistan as an active are system. Geology, v, 3 ,

Girardeau, J., Marcoux, J., Allegre, C.J., Bassuollet,
J.P., Tang Youking, Zao Yougong and Wang Xibin, 1984 . Tectonic environment and geodynamic significance the Neo-Cimmerian Donqia ophiolite, Bangong-N Jiang suture zone, Tibet, Nature, v. 307, p. $27-31$. Hallam, A., 1984a. The unlikelihood of an expro
Earth, Geological Magazine, v, 121, p. 653-655. Hallam, A., 1984b. Continental humid and arid zones
during the Jurassic and Cretaceous. Palneeogeography.
Palaeoelimatology, Palacoecology, v. 47, p. 195-223. Khain, V.E., 1984, The Alpine-Mediterranean fold be of the U.S.S.R. Episodes, v. 7, no. 3, p. 20-29. Kllmetz, M., 1983. Speculations on the Mesozole plate
tectonic evolution of eastern China. Tectonics, v. 2 , teetonic ev
p. $139-166$.

Mascle, G. and Marcoux, J., 1982. Analogies entre le Téthys mésogéenne et la "Tethys ouest americain Consequences. Atti della Acendemin Nazionale dei
Lincei, Rendiconti ciasse di seienze fisiche,
matematiche e naturali, $y, 72, p, 373-379$.

Mitchell, A.H.F., 1981. Phanerozoic plate boundaries in mainland SE Asia, Himalays and Tibet. Journal
Geological Society of London, v. 138, p. 109-122.

Morel, P. and Irving, E., 1981. Paleomagnetism and the evolution of Pangaes. Journal of Geophysical Researeh v. 86, p. 1858-1872.

Neumayr, M., 1885. Die geographische Verbreitung der Juraformation. Denisschriften der kaiserlichen und koniglichen Akademie der. Wissensehaften zu Wien, mathematiseh

Neumayr, M., 1887. Erdgeschichte, vol. Beschreibende Geologie. Veriag des Bibliographisehen

Owen, H.G., 1983. Atlas of Continental Displacement, 200 Million Years to the Present. Cambridge University

Savostin, L.A., Sibuet, J.-C., Zonenshain, L.P., L Piehon, $X$. and Roulet, M.-J., in press. Kinematic
evolution of Tethys belt from the Atlantic ocean of Pamir since Triessic. Teetonophysies.

Schuchert, C., 1928. The hypothesis of entinenta: displacement. Int Theory of Continental Drif. Oklahoma, p. 104-144.

Sengör, A.M.C., 1979. Mid-Mesozoic elosure of v. 279, p. 590-593.
Sengore, A.M.C, 1981. The evolution of Palaeo-Tethys In the Tibetan segment of the Alpides. In: Geological and Eeological Studies of the Qinghiai-Xizan Sengor, A.M.C, 1984. The Cimmeride Orogenic System Sengor, A.M.C, 1984. The Cimmeride Orogenic System
und the Tectonies of Eurasia. Geological Society of
Amerien Special Paper 195, p. xi+82.

Sengör, A.M.C, in press. Die Alpiden und die Geologische Bundsehaun.

SSengör, A.M.C. and Hsih K.J, in press. The Cimmerides of Eastern Asiat History of the eastern end of Prance. Sengor, A.M.C. Yutmaz, Y. and Sungurlu, O, 1985.
Teetonies of the Mediterranean Cimmerides nature and evolution of the western termination of Palaeo-Tethys. In: Geological Evolution of the Eastern Mediterranean Geological

Smith, A.G., 1921. Alpine deformation and the oceanic areas of the Tethys, Mediterranean and Atlantic. p. 2039-2070.

Smith, A.G., 1973. The so-ealled Tethyan optiolites. In arling, D.H. and Runcorn, S.K. (eds.), Implications of Continental Drift to the
Press, London, p. 977-986.

Smith, A.G., Hurley, A.M. and Briden, J.C., 1981. Phanerozole Peleocontinental World Maps. Cambridge
University Press, Cambridge, 102p.

Staub, R., 1928. Der Bewegungsmechanismus der Erde. Gebrider Borntrageger, Berlin, $270 \mathrm{p}$

Stille, H., 1949. Das Leitmotiv der geotektonisehen Erdentwicklung. Deutsche Akademie de
Wissensehaften zu Berlin, Vortrigge und Schififten, v. 32 p. 1-27.

Stocklin, J., 1974. Possible ancient continental margins Geology of Continental Margins, Springer-Vering. Berlin, p. 873-887.
Stócklin, J., 1983. Himalayan orogeny and Eart expansion. Ins s.w. Carey, (ed.), Expanding Esrtt
Symposium, University of Tasmania, Hobert, p. 119-130. Suess, E., 1893. Are great ocean depths permenent? Natural Seience, v. 2, p. 180-187.

Suess, E., 1895. Note sur Thistoire des océans. Comptes-Rendus Hébdomadaires de PAcademie de Suess, E., 1909. Das Antlitz der Erde, v. 3/1L. Tempsiky, Wien, 789p. Tapponnier, P., Peltzer, G. and Armijo, R., in presse On Vail, P.R., Hardenbol, J. and Todd, R.G., in press. Jurnssie uneonformities, ehronostratigraphy and biostratigraphy. In: Ameriean Association of Petroleum Geologists Memoir on Interregional Unconformities. Van der Voo, R., Peinado, J. and Seotese, C.R., 1984. A Recomagnetic reevaluation of Pangaea Reconstruetion from Paleozole Paleomagnetism), v. 12 , p. 11-26.

Westphal, M., Bazhenov, M.l., Lauer, J.-P., Pechersky, mplications of the evolution of the Tethys belt from the Atlantic the evolution of the Tethys beit from Wilson, J.T., 1963. Hypothesis of Earth's behaviour.

Zhang, Zh.M., Liou, J.G. and Coleman, R.G., 1984. An outline of the plate tectonies of China. Geologica 